\begin{tabular}{l} 
2. To: (Receiving Organization) \\
Distribution \\
5. Proj./Prog./Dept./Div.: \\
SNF Project/W- 441 \\
\hline
\end{tabular}

8. Originator Remarks:

For approval and release.

3. From: (Originating Organization)
Technical Integration
$\begin{aligned} & \text { 6. Design Authority/Design Agent/Cog. Engr.: } \\ & \text { C. C. Pitkoff }\end{aligned}$

3. From: (Originating Organization)

C. C. Pitkoff
4. Related EDT No:

NA

7. Purchase Order No:

NA

9. Equip./Component No.:

NA

10. System/Bldg./Facility:

CVDF/142K

12. Major Assm. Dwg. No.

NA

13. Permit/Permit Application No.: NA

14. Required Response Date:

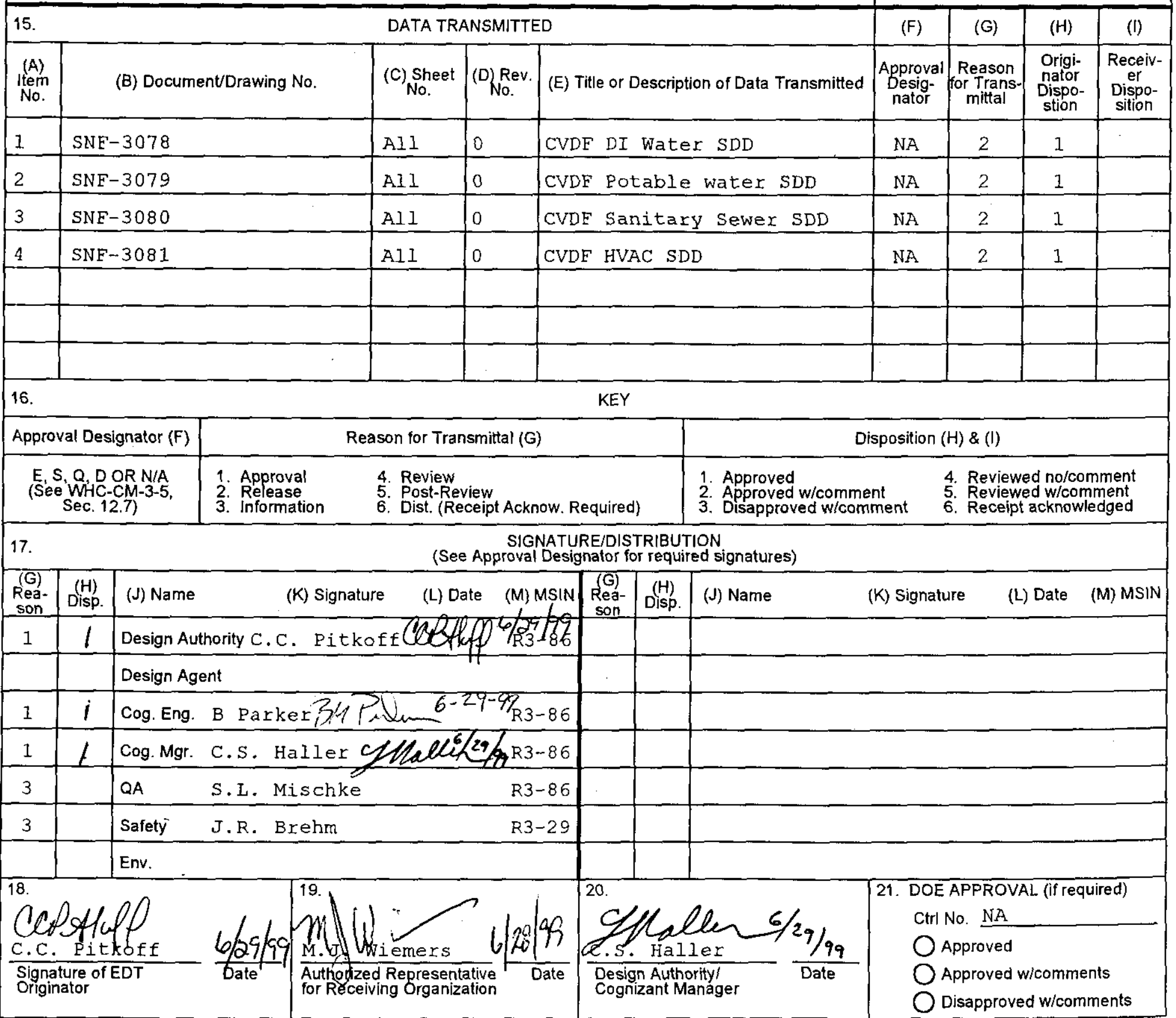

BD-7400-172-2 (10/97)

BD-7400-172-1 


\section{Cold Vacuum Drying Facility Potable Water System Design Description}

\section{C. Pitkoff}

\section{DE\&S Hanford,}

Richland, WA 99352

U.S. Department of Energy Contract DE-AC06-96RL13200

EDT/ECN: $6263 \theta^{\circ}{ }^{\circ}(\mathrm{JKB} 6 \mathrm{~b} / 30 / 99)$

Org Code: 2F800

UC: 510

B\&R Code: $39 \mathrm{EW} 70400$

CACN: 105568

COA: $\mathrm{A} 000$

Total Pages: 27(JKB 6130/99)

Key Words: SNF, CVD, W-441, design description, potable water

Abstract: This document describes the Cold Vacuum Drying Facility (CVDF) potable water (PW) system. The PW system provides potable water to the CVDF for supply to sinks, water closets, urinals, showers, custodial service sinks, drinking fountains, the decontamination shower, supply water to the non-PW systems, and makeup water for the de-ionized water system.

TRADEMARK DISCLAIMER. Reference herein to any specific commercial product, process, or service by trade name, trademark, manufacturer, or otherwise, does not necessarily constitute or imply its endorsement, recommendation, or favoring by the United States Government or any agency thereof or its contractors or subcontractors.

Printed in the United States of America. To obtain copies of this document, contact: Document Control Services. P.0. Box 950. Mailstop H6-08. Richland WA 99352. Phone (509) 372-2420; Fax (509) 376-4989.
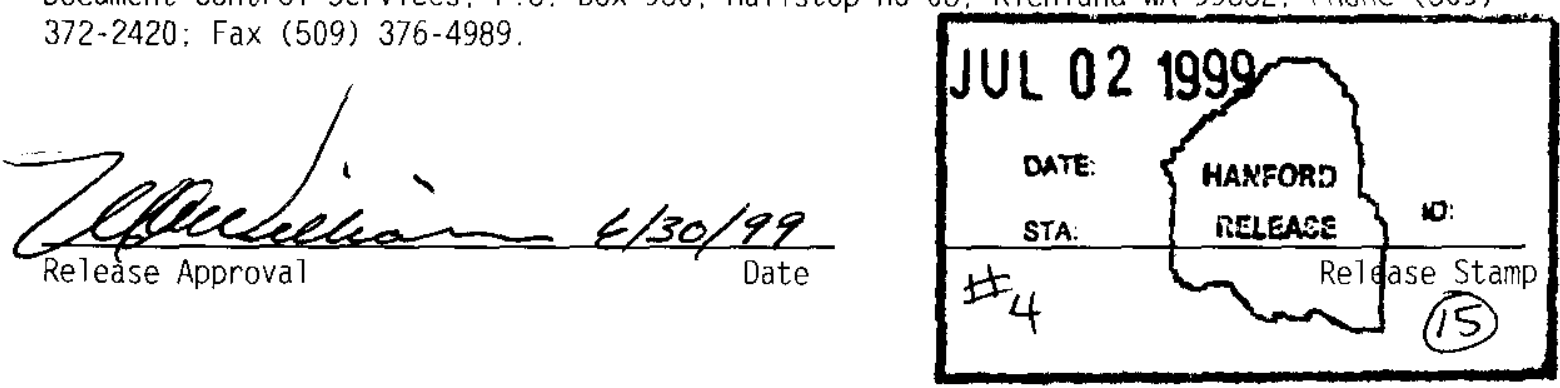

\section{Approved for Public Release}


SNF-3079 Rev. 0

\section{COLD VACUUM DRYING FACILITY}

POTABLE WATER SYSTEM

DESIGN DESCRIPTION

SYSTEM 26 


\section{TABLE OF CONTENTS}

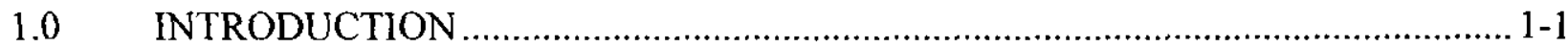

1.1 System Identification .....................................................................................1-1

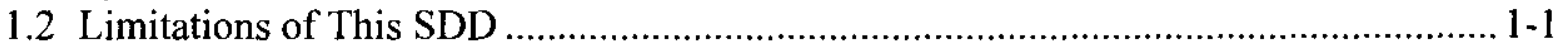

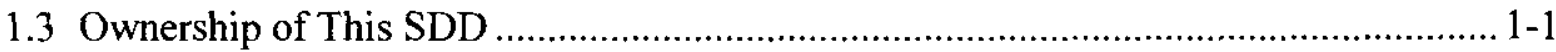

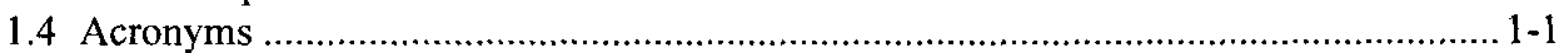

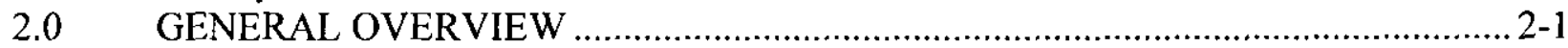

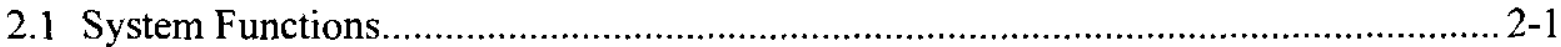

2.2 System Classification ……………................................................................ 2-1

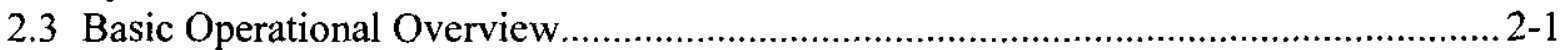

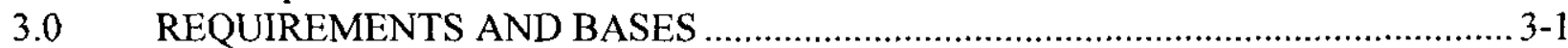

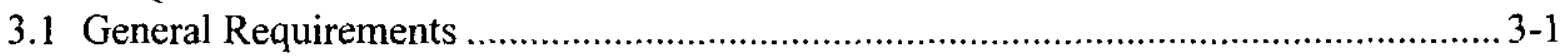

3.1.1 System Functional Requirements ................................................................ 3-1

3.1.2 Subsystem and Major Components ............................................................. 3-2

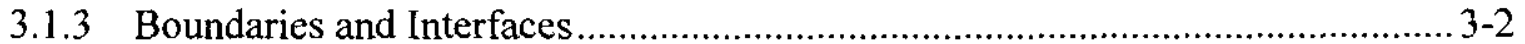

3.1.4 Codes, Standards, and Regulations ............................................................. 3-3

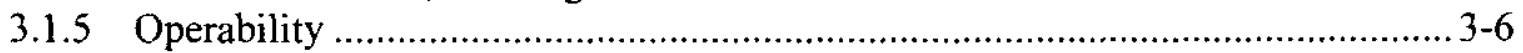

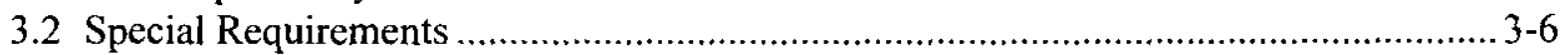

3.2.1 Radiation and Other Hazards ................................................................... 3-6

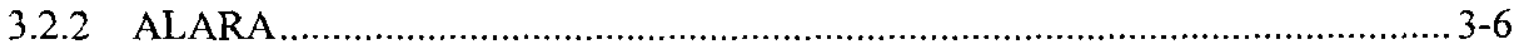

3.2.3 Nuclear Criticality Safety ...................................................................... 3-6

3.2.4 Industrial Hazards ...................................................................................

3.2.5 Operating Environment and Natural Phenomena ........................................... 3-6

3.2.6 Human Interface Requirements ................................................................. 3-6

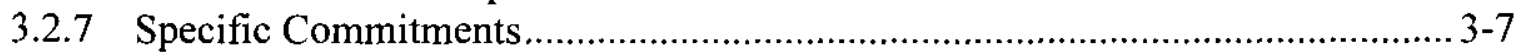

3.3 Engineering Disciplinary Requirements.............................................................. 3-7

3.3.1 Civil and Structural ...............................................................................

3.3.2 Mechanical and Materials ......................................................................... 3-7

3.3.3 Chemical and Process ............................................................................ 3-7

3.3.4 Electrical Power .................................................................................... 3-7

3.3.5 Instrumentation and Control ....................................................................... 3-7

3.3.6 Computer Hardware and Software ................................................................ 3-7

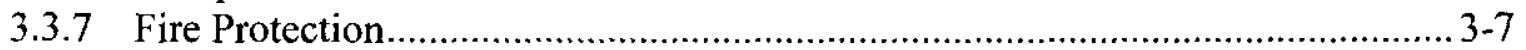

3.4 Testing And Maintenance Requirements ............................................................ 3-8

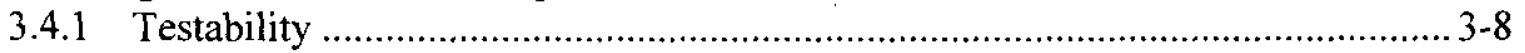

3.4.2 TSR-Required Surveillances.................................................................. 3-8

3.4.3 Non-TSR Inspections and Testing ...........................................................

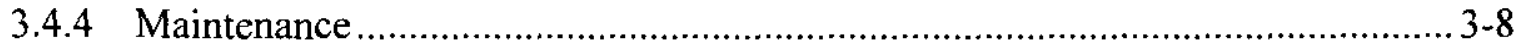

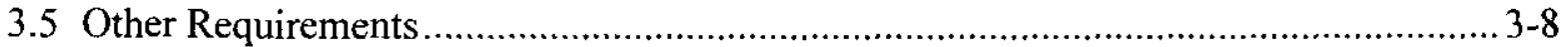

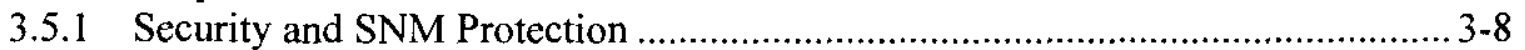

3.5.2 Special Installation Requirements............................................................ 3-8

3.5.3 Reliability, Availability, and Preferred Failure Modes........................................ 3-8

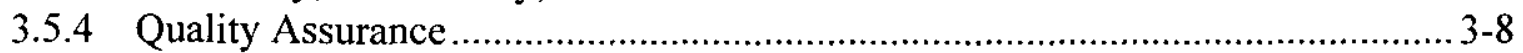

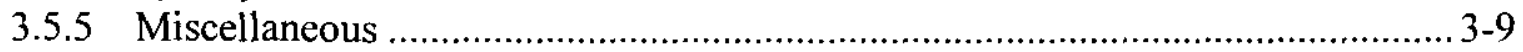

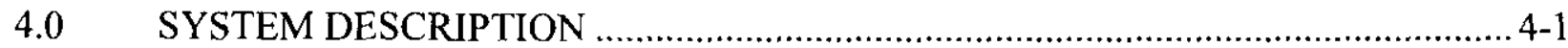




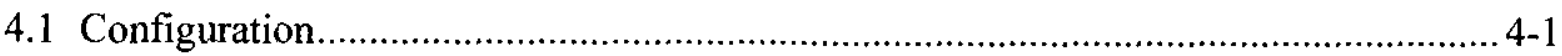

4.1.1 Description of System, Subsystems, and Major Components ............................ 4-1

4.1.2 Boundaries and Interfaces....................................................................... 4-2

4.1.3 Physical Location and Layout.................................................................... 4-2

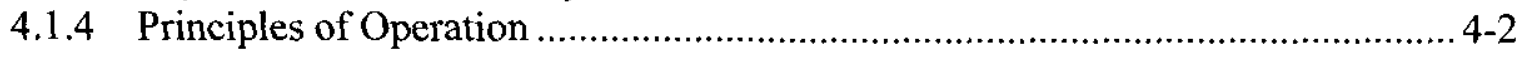

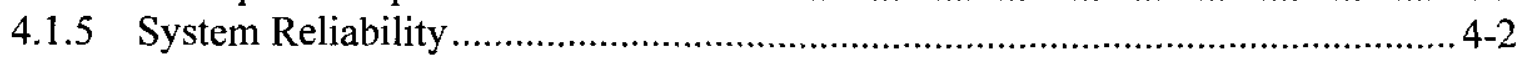

4.1.6 System Control Features ....................................................................... 4-2

4.2 Operations................................................................................................. 4-2

4.2.1 Initial Configurations (Pre-startup) ..................................................... 4-2

4.2.2 System Startup ................................................................................. 4-3

4.2.3 Normal Operations................................................................................. 4-3

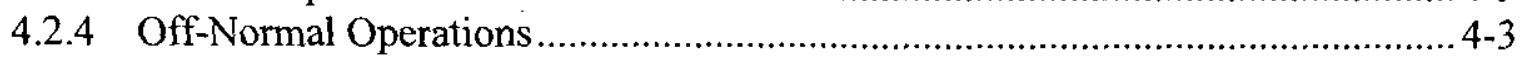

4.2.5 System Shutdown ................................................................................ 4-3

4.2.6 Safety Management Programs and Administrative Controls............................. 4-3

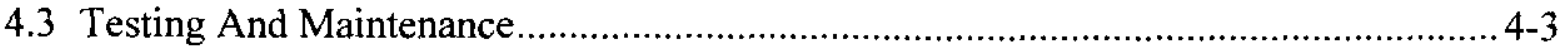

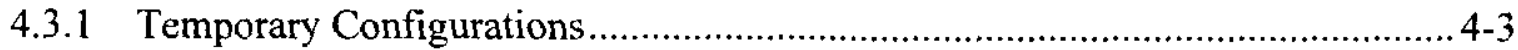

4.3.2 TSR-Required Surveillances............................................................. 4-3

4.3.3 Non-TSR Inspections, and Testing ......................................................... 4-3

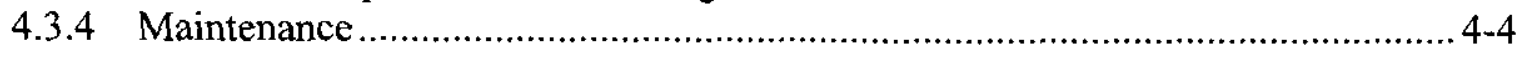

\section{APPENDICES}

APPENDIX A. Source Documents................................................................................ A-1

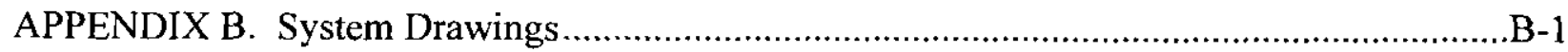

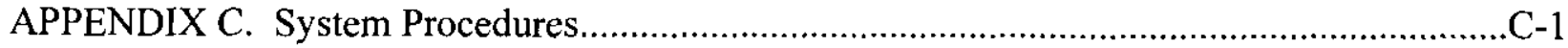


SNF-3079 Rev. 0

\section{LIST OF FIGURES}

Figure 3-1. PW System Layout............................................................................................. 3-4

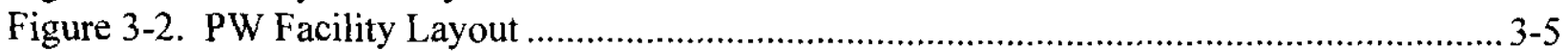




\subsection{INTRODUCTION}

\subsection{System Identification}

This system design description (SDD) addresses the potable water (PW) system that supplies water to the Cold Vacuum Drying (CVD) Facility for general use and to the de-ionized water system to support the CVD process. This system is comprised of: (1) the incoming water supply line; (2) the building PW pipelines; and (3) isolation valves, check valves, and backflow preventers. Figures 3-1, 3-2, and 3-3 show a general layout of this system.

The following provides an abbreviated list of drawings applicable to the $\mathrm{PW}$, a more complete list is in Appendix B, "System Drawings", H-1-82222, Cold Vacuum Drying Facility Mechanical Utilities WTR \& Compressed Gases P\&ID, H-1-82227, Cold Vacuum Drying Facility Mechanical Utilities $1^{\text {st }}$ Floor Water Systems, H-1-82228, Cold Vacuum Drying Facility Mechanical Utilities $2^{\text {nd }}$ Floor Process Chilled Water.

This SDD, when used in conjunction with the other elements of the definitive design package, provides a complete picture of the PW for the CVD Facility. Elements of SDD include functions, requirements, and descriptions. Other documents comprising the definitive design include:

- $\quad$ Project design requirements (HNF-SD-SNF-DRD-002),

- Master Equipment List (SNF- 4148),

- Data and calculation matrix tracking list (SNF-3001),

- $\quad$ Sequence of operations (HNF-2356).

\subsection{Limitations of This SDD}

This SDD has been prepared with best available information taken from reviewed and approved design documents and drawings. As the design and construction proceed to completion this SDD will be revised to incorporate design changes, construction information, as-builts and testing/operation/maintenance data as appropriate.

\subsection{Ownership of This SDD}

The CVD Facility Design Authority assigned to the PW system is responsible for the accuracy and technical content of this SDD. Any questions on the system or content of this document shall be resolved through the design authority.

\subsection{Acronyms}

CVD Cold Vacuum Drying

PAL Pressure Alarm Low

Psig Pounds Per Square Inch Gage

PT Pressure Transmitter 
SNF-3079 Rev. 0

$\begin{array}{ll}\text { PW } & \text { Potable Water } \\ \text { RPBP } & \text { Reduced Pressure Backflow Preventer } \\ \text { SDD } & \text { System Design Description } \\ \text { SNF } & \text { Spent Nuclear Fuel }\end{array}$




\subsection{GENERAL OVERVIEW}

\subsection{System Functions}

The PW system provides potable water to the CVD Facility for supply sinks, water closets, urinals, showers, custodial service sinks, drinking fountains, the decontamination shower, supply water to the non-PW systems, and makeup water for the de-ionized water system.

\subsection{System Classification}

The system is classified as general service and Performance Category (PC) 1 .

\subsection{Basic Operational Overview}

The PW system supplies water to the CVD Facility through a pipe running from the $100 \mathrm{~K}$ Area sanitary water loop east of the CVD Facility. The pipe enters the east side of the administrative office building, is reduced and runs through back-flow preventers and ball valves to plumbing fixtures (toilets, lavatories, sinks, drinking fountains, showers, and water heaters), and the nonPW systems for the floor drain traps and hose bibs. The PW system also supplies makeup water to the de-ionized water system through the connection to the non-potable water system. Drawing H-1-82222 (Zone C-7) shows the details of this system. 
SNF-3079 Rev. 0

\subsection{REQUIREMENTS AND BASES}

\subsection{General Requirements}

\subsubsection{System Functional Requirements}

Functional requirements of the potable water system include design requirements, safety requirements, environmental requirements, mission critical requirements, and general requirements.

\subsubsection{Design Requirements (if applicable)}

1. Requirement: PW shall be supplied to the facility from an existing water main from the $167-\mathrm{K}$ cross-tie tunnel. A reduced pressure backflow preventer (RPBP) shall be installed in the CVD Facility.

Basis: HNF-SD-SNF-DRD-002, Rev 4, Section 6.6.4.4. This is the closest, practical source to receive $\mathrm{PW}$ from.

How the system meets the requirement: The design media implements this requirement. Drawing H-1-82092 shows this routing.

2. Requirement: Potable cold water shall supply the sinks, the restrooms, the custodial service sinks, the drinking fountains, and the showers. Water shall be heated by tank-type electric water heaters that are sized to provide adequate hot water for the restrooms and showers in the administration area and to serve the safety shower in the process support area.

Basis: HNF-SD-SNF-DRD-002, Rev 4, Section 6.6.4.4, and standard design practices.

How the system meets the requirement: The design media implements these requirements. Drawing H-1-82227 shows details of this implementation.

3. Requirement: The system shall supply water for the non-PW system and the traps for the floor drains in Rooms 120 and 207 in the process support area which are connected to the sanitary water collection system.

Basis: HNF-SD-SNF-DRD-002, Rev 4, Section 6.6.4.4, and best engineering practices.

How the system meets the requirement: The design media implements this requirement. Drawing H-1-82227 shows details of this implementation.

4. Requirement: The system shall supply makeup water to the de-ionized water and chilled/cooling water system. The de-ionized water system is described in SDD SNF3078 . 
Basis: HNF-SD-SNF-DRD-002, Rev 4, Section 6.6.4.4, and best engineering practices.

How the system meets the requirement: The design media implements this requirement. Drawing H-1-82227 shows details of this implementation.

5. Requirement: There shall be no potable water lines in the process area of the building except to serve eye washes, the de-ionized water system, and safety showers.

Basis: HNF-SD-SNF-DRD-002, Rev. 4, Section 6.6.4.4.

How the system meets the requirements: The design media implements this requirement. Backflow preventors are provided between the potable water system and process systems. Drawing H-1-82222 shows details of this implementation.

\subsubsection{Safety Requirements}

3.1.1.2.1 Safety Class Requirements. There are no safety class requirements for the COMM system.

3.1.1.2.2 Safety Significant Requirements. There are no safety significant requirements for the COMM system.

3.1.1.2.3 Other Safety Requirements. There are no other safety requirements for the COMM system.

3.1.1.3 Environmental Requirements. There are no environmental requirements for the COMM system.

3.1.1.4 Mission-Critical Requirements. There are no mission-critical requirements for the COMM system.

3.1.1.5 General Requirements. General requirements are presented by system in Section 3.1.2.

\subsubsection{Subsystem and Major Components}

The major components include the incoming supply and building water lines, isolation valves, pressure control valves, flow control valves, pressure transmitter (PT) and pressure alarm low indicator, check valves and back-flow preventers, electric hot water tanks, and hose bibs. There are no special requirements beyond those specified in the National Codes and Standards applicable to individual components.

\subsubsection{Boundaries and Interfaces}

The system boundaries are from the tie-in to the PW system at $165-\mathrm{KW} / 190-\mathrm{KW}$ at valve PWV001 , to the east side of the CVD Facility administration building, the administration building 
piping, the process support area piping to the emergency shower in room 117 , the de-ionized water system in the transfer corridor (Room 120), and the non-PW system on the second floor mechanical room (Room 207).

The system interfaces with the PW supply lines in $165-\mathrm{KW} / 190-\mathrm{KW}$, the sanitary services and hot water heaters in the administration area, the emergency shower in room 117 , the de-ionized water system located in Room 120 of the process support area, and the non-PW system and floor drain in mechanical equipment room (Room 207). The system also interfaces with the facility monitoring and control system (MCS) through PT 9020 located in Room 117 and low-pressure alarm readout in Room 107. The piping interfaces are equipped with back-flow preventers, flow control valves, pressure reducers, and line size reducers as necessary. See Figures 3-1 and 3-2 for details.

\subsubsection{Codes, Standards, and Regulations}

- $\quad$ ANSI Z358.1, 1990, Emergency Eyewash and Shower Equipment, American National Standards Institute, New York, New York. 


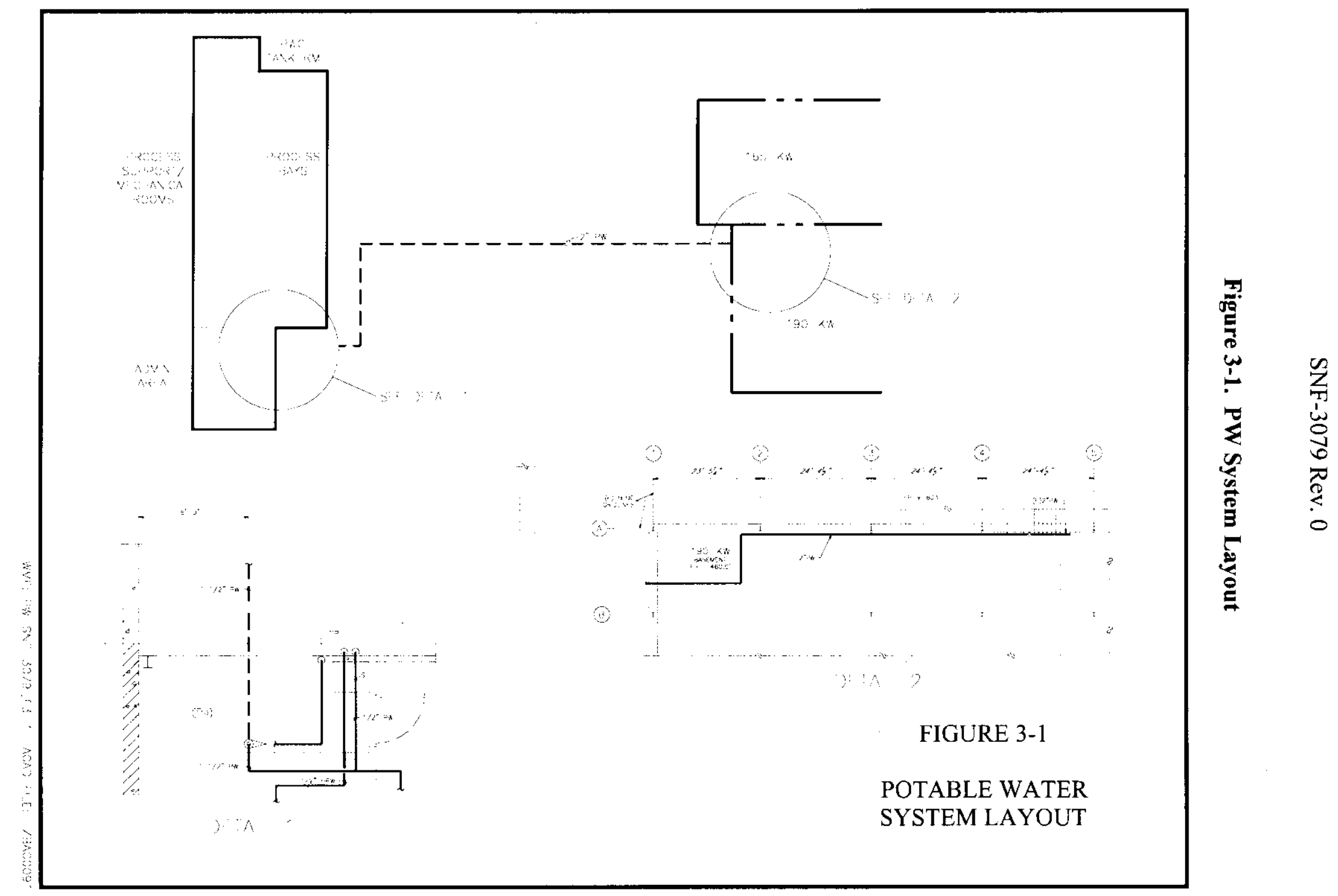


SNF-3079 Rev. 0

Figure 3-2. PW Facility Layout

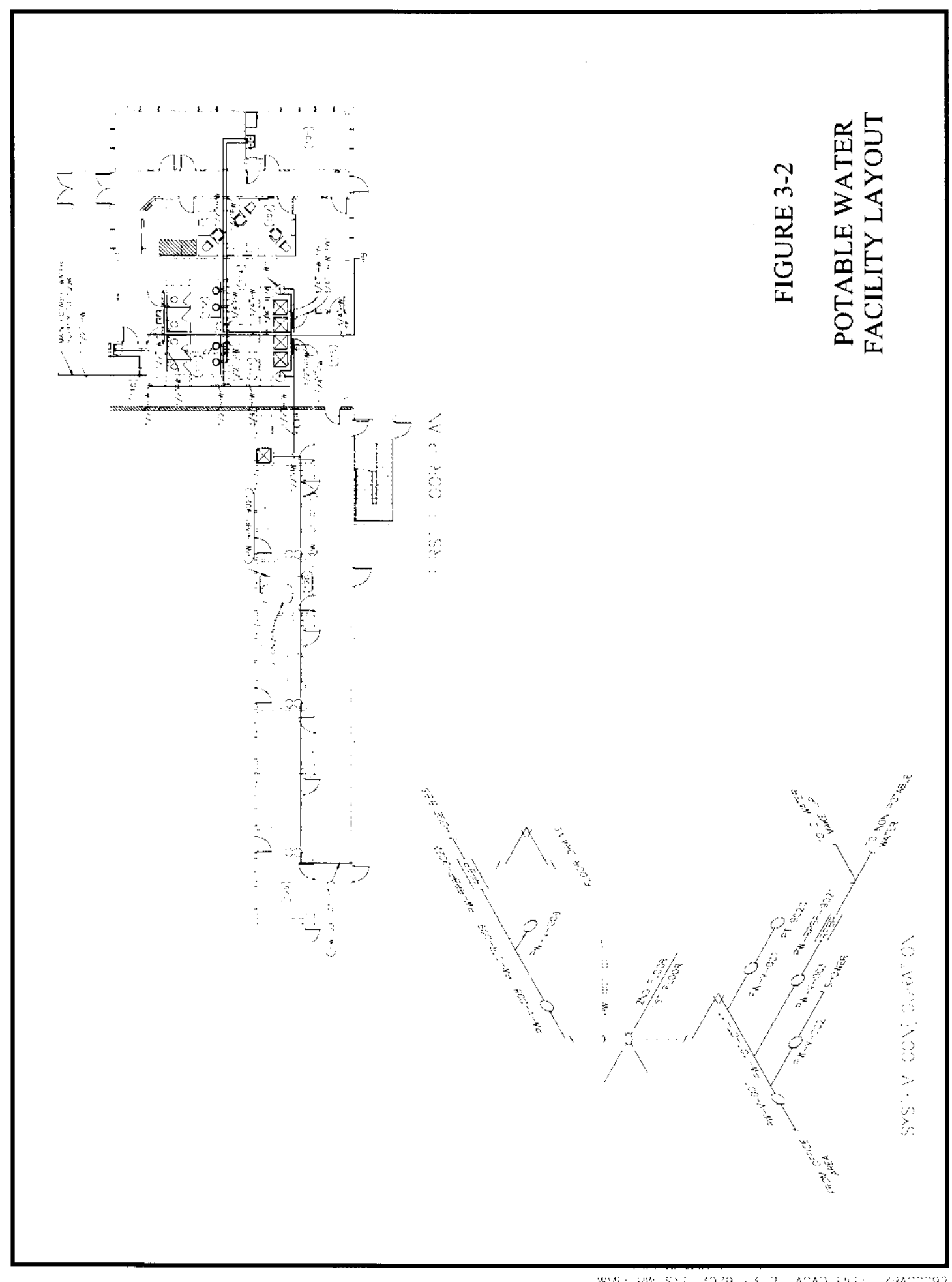


- AWWA, 1995, Cross Connection Control Manual: Accepted Procedure and Practice, 6th Edition, Pacific Northwest Section, American Water Works Association, Denver, Colorado.

- $\quad$ AWWA C652, Disinfection of Water Storage Facilities, American Water Works Association, Denver, Colorado.

- UBC, 1994, Uniform Building Code, International Conference of Building Officials, Whittier, California.

- UPC, 1994, Uniform Plumbing Code, International Association of Plumbing and Mechanical Officials, Walnut Creek, California.

\subsubsection{Operability}

There are no unique operability requirements for this system.

\subsection{Special Requirements}

\subsubsection{Radiation and Other Hazards}

This section does not apply to this SDD.

\subsubsection{ALARA}

This section does not apply to this SDD.

\subsubsection{Nuclear Criticality Safety}

This section does not apply to this SDD.

\subsubsection{Industrial Hazards}

1. Requirement: The hot water temperature will be set no higher than 120 degrees $F$ at completion of testing to prevent possible scalding of workers when using sinks and showers. All other potential industrial hazards are addressed via operating procedures.

Basis: Good operating practice and personnel safety requirements.

How the system meets the requirement: Final adjustment of the settings will be specified in the test procedures developed as part of the Test Specification.

\subsubsection{Operating Environment and Natural Phenomena}

This section does not apply to this SDD.

\subsubsection{Human Interface Requirements}


There are no unique human interface requirements not covered by National Codes and Standards.

\subsubsection{Specific Commitments}

This section does not apply to this SDD.

\subsection{Engineering Disciplinary Requirements}

\subsubsection{Civil and Structural}

1. Requirement: The PW supply pipe shall be buried at least 4 feet from ground surface and a detectable plastic marker tape shall be buried 1 foot below grade directly over the pipeline.

Basis: Hanford Standards, good construction practices.

How the system meets the requirement: The Construction Specification W-441-C1 provides for implementation of this requirement.

\subsubsection{Mechanical and Materials}

Materials shall be as specified on drawing H-1-82094, Civil Site Utility Details, and in construction specification, W-441-C1.

\subsubsection{Chemical and Process}

This section does not apply to this SDD.

\subsubsection{Electrical Power}

Electrical power will be supplied to this system by the electrical distribution system. Specific requirements for this system are contained in SDD, SNF-3075.

\subsubsection{Instrumentation and Control}

Pressure Alarm Low (PAL) 9020 monitors line PT 9020 on PW-101-CT-1" in the process support area. The read out is monitored by the facility MCS in control room 107 . See $\mathrm{H}-1-82222$ and $\mathrm{H}-1-82296$ sheet 3 of 9.

\subsubsection{Computer Hardware and Software}

This section does not apply to this SDD.

\subsubsection{Fire Protection}


This section does not apply to this SDD.

\subsection{Testing And Maintenance Requirements}

\subsubsection{Testability}

Testing will be performed according to the requirements of specification W-441-C1 and the Construction Test Procedures. Testing includes pressure testing, and disinfectant flushing.

\subsubsection{TSR-Required Surveillances}

This section does not apply to this SDD.

\subsubsection{Non-TSR Inspections and Testing}

Upon completion of installation, the system is to be tested in accordance with the Uniform Plumbing Code, Section 103.5, Inspection and Testing, per paragraph 3.17 of W-441-C1, and the test specification.

\subsubsection{Maintenance}

There are no specific maintenance requirements during the two-year life of the facility.

\subsection{Other Requirements}

\subsubsection{Security and SNM Protection}

This section does not apply to this SDD.

\subsubsection{Special Installation Requirements}

The system shall be sterilized in accordance with AWWA C652. The system is to be disinfected during and after installation per paragraph 3.18 of Section 02700 of W-441-Cl. The construction specification also requires a certificate of disinfection be submitted.

\subsubsection{Reliability, Availability, and Preferred Failure Modes}

The PW system will remain in continuous service during the two year life of the CVD Facility.

\subsubsection{Quality Assurance}

The PW system fabrication quality assurance/quality control program is based on the safety designation of the SSCs as detailed in SNF-4148, Cold Vacuum Drying Facility Master Equipment List and the application of a graded approach as described in HNF-MP-599, Project Hanford Quality Assurance Program Description. 


\subsubsection{Miscellaneous}

A conceptual decontamination and decommissioning plan for the CVDF, as identified in the guidelines of DOE-STD-3009-94, Preparation Guide for U.S. Department of Energy Nonreactor Nuclear Facility Safety Analysis Reports, is included in HNF-SD-SNF-SAR-002. 
SNF-3079 Rev. 0

\subsection{SYSTEM DESCRIPTION}

\subsection{Configuration}

\subsubsection{Description of System, Subsystems, and Major Components}

The PW system ties in to an existing potable water supply line in the basement of the $190-\mathrm{KW}$ building with a 2 -inch tee, ball valves and unions. The supply line is then routed through the $190-\mathrm{KW}$ basement walls in a westerly direction under 4 feet of soil to the CVD Facility administration area. The tie-in is shown on H-1-82094 and the underground piping route shown on $\mathrm{H}-1-82092$.

The water supply line is reduced to a 1.5 -inch line near the CVD Facility and routed under the floor slab of Room 110 entering the room through a riser to a Y-strainer and pressure regulating valve with integral by-pass/safety relief and isolation valves. Refer to drawing H-1-82227.

From Room 115, the 1.5-inch line is routed through the ceiling area in the administration area on trapeze hangers as shown on drawing $\mathrm{H}-1-82231$ and reduced in size from 1.5 to 1.25 and $3 / 4$ inches to supply cold water to various plumbing fixtures in Rooms 111,1.12,113, and 114. Cold water is supplied to the two, residential-type, electric, 52-gal. hot water heaters in the utility rooms adjacent to rooms 113 and 114 . Hot water is then distributed from the hot water heaters via $3 / 4$-inch lines to the sinks and showers in rooms $111,112,113$, and 114.

Potable water to the process support area is supplied from a branch connection in Room 115 of the administrative area. The 1.25-inch cold water line, PW-101-CT-1 1/4", continues Room 115 in a northerly direction in the ceiling through the wall between in the administration area and Room 116 in the process support/mechanical room to supply the emergency shower in Room 117. The line has a ball valve (PW-V-001) in line as it enters the process support area. A $1 / 2$-inch cold water line tees off from PW-101-CT-1 1/4" to supply the emergency shower in Room 117 ball valve (PW-V-002) is provided in-line near the shower. The $3 / 4$-inch hot water line that supplies the administration building showers and sinks is reduced to $1 / 2$-inch and passes through the ceiling and walls to supply the emergency shower in Room 117. The cold and hot water lines terminate at the shower. The $1 / 2$-inch cold water line and the $3 / 4$-inch hot water line have no unique line number designations in Room 117.

PW-101-CT-1 1 1/4" continues through the process area ceiling to supply the de-ionizer in Room 120. The line supplying the de-ionizer is connected to the main line with a tee connection, reduced to 1-inch, equipped with a ball valve (PW-V-003), a reduced pressure back-flow preventer (PW-RPBP-9021), and a flow control valve (FCV 9012) set at $8 \mathrm{gpm}$. A tee is installed in the line between the back-flow preventer PW-RPBP-9021. The backflow preventor is the interface between the potable and non-PW system and flow control valve FCV-9012. The branch from this tee, NPW-001-CT-1", supplies the trap primer for the Room 120 floor drain.

After the tee to the de-ionizer system, line PW-101-CT-1 1/4" is reduced to 1 -inch and renamed PW-101-CT-1". Line PW-101-CT-1" continues north in the ceiling to a 90 degree elbow near 
Room 126 and then proceeds westerly to the west wall of Room 116 . Pressure transmitter PT9020 is connected to this section of PW-101-CT-1" through a tee and ball valve PW-V-007. The pressure transmitter is connected through the MCS to a low-pressure alarm PAL-9020 in the control room (Room 107).

At the western wall of Room 116, PW-101-CT-1 is routed up through the floor into Room 207. There it supplies the potable and non-PW system on the second floor in the mechanical utilities room. A ball valve (PW-V-008) and strainer (PW-STR-009) with ball valve (PW-V-009) attached are provided in-line in Room 207. A reduced pressure back-flow preventer (PW-RPBP9022) with floor drain is installed in-line and represents the interface with the non-PW system on this floor. Downstream of the backflow preventor is pressure control valve PCV-9021 with local pressure indicator. PCV-9021 is set at 13 psig. The pressure control valve includes a bypass valve, NPW-V-002, and two isolation. The bypass line around PCV-9021 is reduced to $1 / 2$ inch. The non-potable line continues and terminates at a hose bid connection labeled NPW-V-004. Refer to drawings $\mathrm{H}-1-82222$, and H-1-82229 Sheets 1 and 2.

\subsubsection{Boundaries and Interfaces}

The PW system interfaces with the de-ionized water system and the non-PW system at RPBP9021, RPBP-9022, and the Facility at the various showers, urinals, etc. Details of these interfaces were provided in the system description (Section 4.1.1) of this document.

\subsubsection{Physical Location and Layout}

The PW system includes piping and components in the $190-\mathrm{KW}$ building basement, direct buried piping (4' depth) to the CVD Facility administration area. The piping then runs throughout the CVD Facility as shown on Drawing H-1-82231.

\subsubsection{Principles of Operation}

Operating procedures will be developed for this system.

\subsubsection{System Reliability}

This system is designed and maintained to be in continuous service for the life of the CVD Facility ( 2 to 5 years).

\subsubsection{System Control Features}

A pressure-regulating valve set at 60 pounds per square inch gage (psig) controls the incoming pressure. It is located in Room 110. The hot water heaters are equipped with temperature controls, and pressure relief.

\subsection{Operations}

\subsubsection{Initial Configurations (Pre-startup)}


The initial configuration (including construction testing) will be as shown on the referenced drawings and as identified in the construction and testing specification.

\subsubsection{System Startup}

Startup, alignment, prerequisite testing, and formal start up activities will be identified in the test specification.

\subsubsection{Normal Operations}

Normal operation of the EFS is described in Section 4.1.4.

Operational procedures providing detailed information on operating modes and activities (including alarm response, shutdown, etc.) will be developed.

\subsubsection{Off-Normal Operations}

There are no off-normal operations anticipated for this system.

\subsubsection{System Shutdown}

Shut off valves are located at the tie in point in $165-\mathrm{KW} / 190-\mathrm{KW}$, in Room 110 of the administrative area, for the emergency shower in Room 117, at the interface with the de-ionizer system in Room 120, and the non-PW systems in Room 207.

\subsubsection{Safety Management Programs and Administrative Controls}

The necessary administrative controls procedures will be developed and incorporated into the operating procedures to prevent manually draining contaminated water from a sump to the retention basin. These procedures will be in compliance with the SNF Integrated Safety Management Plan.

\subsection{Testing And Maintenance}

\subsubsection{Temporary Configurations}

This section does not apply to this SDD.

\subsubsection{TSR-Required Surveillances}

This section does not apply to this SDD.

\subsubsection{Non-TSR Inspections, and Testing}

This section does not apply to this SDD. 
SNF-3079 Rev. 0

\subsubsection{Maintenance}

There is no unique maintenance required due to the system design and short facility life. Maintenance procedures will be developed to address routine maintenance requirements are applied to support system operation. 
SNF-3079 Rev. 0

Appendix A

Source Documents

A-1 
W-441-C1, Construction Specification for the Cold Vacuum Drying Facility, Mactec-Meier and Associates, Kennewick, Washington.

HNF-SD-SNF-DRD-002, 1999, Cold Vacuum Drying Facility Design Requirements, Rev. 4, Fluor Daniel Hanford, Incorporated, Richland, Washington.

HNF-3553, Spent Nuclear Fuel Project Final Safety Analysis Report, Annex B, "Cold Vacuum Drying Facility Final Safety Analysis Report”, DRAFT, DE\&S Hanford, Incorporated, Richland, Washington.

SNF-2356, 1999, Spent Nuclear Fuel Project Cold Vacuum Drying Facility Operations Manual, Numatec Hanford Corporation, Richland, Washington 
SNF-3079 Rev. 0

Appendix B

System Drawings 
H-1-82092, Sheet 1 of 1, Cold Vacuum Drying Facility Civil Site Plan, Legend

H-1-82094, Sheet 1 of 1, Cold Vacuum Drying Facility Civil Site Utility Details

H-1-82222, Sheet 1 of 2, Cold Vacuum Drying Facility Mechanical Utilities WTR \& Compressed Gases P\&ID

H-1-82227, Sheet 1 of 1, Cold Vacuum Drying Facility Mechanical Utilities $1^{\text {st }}$ Floor Water Systems

H-1-82228, Sheet 1 of 1, Cold Vacuum Drying Facility Mechanical Utilities $2^{\text {nd }}$ Floor Process Chilled Water

H-1-82229, Sheets 1and 2 of 2, Cold Vacuum Drying Facility Mechanical Utilities Sections \& Details 
SNF-3079 Rev. 0

Appendix C

System Procedures

C-1 
SNF-3079 Rev. 0

This appendix does not apply to this SDD. 


\section{DISTRIBUTION SHEET}

\begin{tabular}{|c|c|c|c|c|c|}
\hline \multirow{2}{*}{$\begin{array}{l}\text { To } \\
\text { Distribution }\end{array}$} & \multirow{2}{*}{\multicolumn{3}{|c|}{$\begin{array}{l}\text { From } \\
\text { Technical Integration }\end{array}$}} & \multicolumn{2}{|l|}{ Page 1 of 1} \\
\hline & & & & \multicolumn{2}{|c|}{ Date June 14,1999} \\
\hline \multicolumn{4}{|c|}{ Project Title/Work Order } & \multicolumn{2}{|c|}{ EDT No. 626308,62631} \\
\hline \multicolumn{4}{|c|}{$\begin{array}{l}\text { SNF-3061, SNF-3066, SNF-3067, SNF-3072, SNF=3073, SNF-3074, } \\
\text { SNF-3077, SNF-3078, SNF-3079, SNF-3080, SNF-3081 }\end{array}$} & \multicolumn{2}{|l|}{ ECN No. NA } \\
\hline Name & MSIN & $\begin{array}{c}\text { Text } \\
\text { With All } \\
\text { Attach. }\end{array}$ & Text Only & $\begin{array}{l}\text { Attach./ } \\
\text { Appendix } \\
\text { Only }\end{array}$ & $\begin{array}{l}\text { EDT/ECN } \\
\text { Only }\end{array}$ \\
\hline W. C. Alaconis & R3-86 & $\mathrm{X}$ & & & \\
\hline L. L. Blehm & $X 3-86$ & $X$ & & & \\
\hline K. A. Boes & $\mathrm{R} 3-86$ & $X$ & & & \\
\hline J. R. Brehm & $\mathrm{R} 3-86$ & $X$ & & & \\
\hline C. S. Haller & R3-11 & $X$ & & & \\
\hline L. C. McKenzie & $\mathrm{S} 2-45$ & $X$ & & & \\
\hline S. L. Mischke & $\mathrm{R} 3-86$ & $\mathrm{X}$ & & & \\
\hline C. C. Pitkoff & $\mathrm{R} 3-86$ & $X$ & & & \\
\hline CVD Project File & R3-86 & $X$ & & & \\
\hline SNF Project File & R3-11 & $X$ & & & \\
\hline
\end{tabular}

